\title{
Characterization of Three Date Palm Cultivars Based on RAPD Fingerprints and Fruit Chemical Composition
}

\author{
D.A. El-Rayes \\ Department of Plant Production and Protection, College of Agriculture \\ and Veterinary Medicine, Qassim University, Al- Qassim, \\ P.O. Box 1482, Buraydah, Saudi Arabia \\ diaelrayes@hotmail.com
}

Abstract. The interspecific and intergenetic relationships of three date palms (Phoenix dactylifera L.) cultivars (namely: Yellow Sukkary, Red Sukkary, and Naptet Sukkary) were investigated. The chemical analysis included the fruit antioxidants activity and efficiency, total bound and free phenolics, flavonoids and carotenoids contents. Data showed that antioxidant extraction with ethanol: water (1:1) solvent gave the highest antioxidant activity ("Oxygen Radical Absorbance Capacity" values) (ORAC FL) and highest antioxidant efficiency (AE). "Red Sukkary" cultivar showed significantly higher values of bound protocatechuic, caffeic, coumaric, ferulic, hydroxy benzoic, and hydroxy cinnamic acids. Whereas "Yellow Sukkary" cultivar contained significantly higher values of free protocatechuic, vanillic, syringic, and hydroxy benzoic acids compared with all other cultivars. No free vanillic acid was detected in "Red Sukkary", whereas no free protocatechuic acid was detected in "Naptet Sukkary" cultivar. The highest content of flavonoids was presented in "Red Sukkary" (4.47 $\mathrm{mg} / 100 \mathrm{~g}$ fresh weight), followed by "Naptet Sukkary" (2.26 $\mathrm{mg} / 100 \mathrm{~g}$ fresh weight) and "Yellow Sukkary" (2.13 mg/100g fresh weight). In addition, total carotenoids contents in fresh date fruits of both "Red Sukkary" and "Naptet Sukkary" cultivars were significantly higher than those of "Yellow Sukkary". The suitability of randomly amplified polymorphic DNA (RAPD) fingerprints as a genetic marker in date palm was tested. Three date palm cultivars (Red Sukkary, Yellow Sukkary, and Naptet Sukkary) were subjected to DNA fingerprint analysis. From 40 primers tested, only 16 were selected as reproducible, giving 115 bands. The RAPD profiles obtained were successfully used to differentiate the genotypes. Based on the pairwise comparison of amplification products, the genetic similarity was 
estimated. The three date palm cultivars showed variation at the DNA level. The genetic similarity among all date palm cultivars ranged from 81 to $87 \%$. Naptet Sukkary was quite distant from other cultivars. A dandrogram was constructed using UPGMA analysis. On the basis of this analysis, the populations were clustered into two clusters: cluster I contained Red Sukkary and Yellow Sukkary cultivars, and cluster II contained Naptet Sukkary cultivar. Therefore, the polymorphism detected and its reproducibility suggest that RAPD markers can be used successfully for varietals identification and for studying the genetic diversity of cultivars.

Keywords. Phoenix dactylifera L., genetic markers, fruit phenolic content (TPC), antioxidant activity.

\section{Introduction}

Date palm is a major fruit tree in most of Arabian countries and it is considered one of the most important commercial crops in the Arab World (FAO, 1984). 'Sukkary', is the most popular date cultivar in Saudi Arabia.

Interest in phytochemical contents and antioxidant activity of fruits and vegetables has been very high in recent years. Recent studies have shown that the majority of antioxidant activity in fruits or vegetables may originate from the polyphenolic compounds (Wang, et al., 1996; Velioglu, et al., 1998 and Eberhardt, et al., 2000). The presence of phenolic compounds in fruits and vegetables has been studied fairly well. In addition to their important functions in plant defense mechanisms and external stresses (Feucht, et al., 1992; Wang, et al., 1994 and Mayr, et al., 1996), they also affect the quality, color and taste of the fruits and their products like juice and fruit slice (Robards, et al., 1999; Bushway, et al., 2002 and Van der Sluis, et al., 2002). In low concentration, phenolics may protect food from oxidative deterioration; however at high concentration, they (or their oxidation products) may participate in discoloration of foods (Robards, et al., 1999 and Bushway, et al., 2002). As shown for apple fruits, the coloration after oxidation depends on the balance between the hydroxycinnamics phenolics and flavonols (Amiot, et al., 1992 and Goupy, et al., 1995).

Date fruits are an excellent source of phenolics and therefore possess an extremely high antioxidant capacity. Date fruits have been reported to contain various phenolics, such as protocaechuic, p. hydroxy benzoic, 
vanillic, syringic, caffeic, coumaric, ferulic, hydroxy benzoic, hydroxy cinnamic acids (Al-Farsi, et al., 2005), which contribute significantly to total antioxidant activity.

Flavonoids exist widely in the plant kingdom and are especially common in leaves, flowering tissues and fruits (Larson, 1988). Plant flavonoids are an important part of the diet because of their effects on human nutrition. Known properties of the flavonoids include: free radical scavenging and strong antioxidant activity (Frankel, 1995).

Characterization of some important chemical compositions of the date fruit and analysis of the available genetic diversity constitute an indispensable step with regard to the expansion of the cultivation of cultivars with universally high demand. Correct identification of trees is usually not possible until fruit are produced. In addition, the characterization of cultivars and evaluation of genetic diversity require a large set of phenotypic data that are often difficult to assess and sometimes variable due to environmental influences. Recently, molecular techniques based on DNA have been very successful in typing cultivars of a variety of crop plants.

The objective of this study was to evaluate both the characterization of some important chemical compositions of three date fruit cultivars and the suitability of randomly amplified polymorphic DNA (RAPD) fingerprints as genetic marker in to distinguish between cultivars.

\section{Materials and Methods}

\section{Plant Material}

Fifteen years old date palms (Phoenix dactylifera L.) of three different cultivars (Yellow Sukkary, Red Sukkary, and Naptet Sukkary) grown at the Research and Experimental Station, College of Agriculture and Veterinary Medicine, Qassim University, Buraydah, Al-Qassim, Kingdom of Saudi Arabia, were selected for the study. All palms were mature, of the same age, and almost uniform in growth. The palms were in good physical condition, free from insect damage and diseases and were subjected to the same horticultural management treatments.

Fruits were harvested at ripening stage, and immediately after harvest, were transported to the postharvest laboratory for chemical 
characters study, whereas young white leaves were collected for DNA extraction for RAPD fingerprints studies.

Fruit samples (ten fruits per replicate) were frozen immediately for determinations of antioxidants activity and efficiency, phenolic contents (PC), flavonoids and carotenoids contents.

\section{Antioxidants and Phenolics Extraction Method}

There are no satisfactory solvent extraction methods suitable for the isolation of all classes of food antioxidants and phenolics or even for a specific class of these components. This is due to the chemical nature of food antioxidants and phenolics, which vary from being simple to very highly polymerized (Shahidi and Naczk, 2004). Therefore, the extraction of antioxidant compounds and total phenolics was carried out using four different solvents which had been used in other studies (Ou, et al., 2001; Vinson, et al., 2001; Kalt, et al., 2001 and Huang, et al., 2002). The fruit sample was extracted using $40 \mathrm{~mL}$ of water, phosphate buffer $75 \mathrm{mM}$, ( $\mathrm{pH} 7.4$ ), ethanol (containing $0.1 \%$ formic acid), or ethanol: water (1:1 $\mathrm{v} / \mathrm{v})$.

\section{Antioxidant Activity $\left(\mathrm{OR} A C_{F L}\right)$ and Efficiency}

Antioxidant activity was measured (as "Oxygen Radical Absorbance Capacity" (ORAC)) according to the method of Ou, et al. (2001). A 150 $\mu \mathrm{L}$ sample extract was introduced into a $3 \mathrm{~mL}$ fluorescence cell, followed by $150 \mu \mathrm{L}$ of $0.12 \mu \mathrm{M}$ disodium FL solution, and $2.55 \mathrm{~mL}$ ethanol: water $(1: 1 \mathrm{v} / \mathrm{v})$. Ethanol: water $(1: 1 \mathrm{v} / \mathrm{v})$ was used as a blank, and Trolox (a water-soluble $\alpha$ tocophenol analogue) at $2.5,5$, and $10 \mu \mathrm{M}$ was used as a standard. The cell was incubated at $37^{\circ} \mathrm{C}$ for $15 \mathrm{~min}$ in a water bath. The initial fluorescence $(f 0)$ was measured at the excitation wavelength of $515 \mathrm{~nm}$ using an RF-540 Shimadzu spectrofluorophotometer (Shimadzu, Kyoto, Japan). After $f 0$ has been recorded, $150 \mu \mathrm{L} 320 \mathrm{mM}$ AAPH reagent, as a free radical generator, was added into a cell and mixed well using a glass rod. Fluorescence was measured and recorded every $5 \mathrm{~min}$ $(f 5, f 10, f 15, \ldots, f 20)$ until the fluorescence of the last reading declined by $>95 \%$ from the first reading $(\sim 60 \mathrm{~min})$. 
The relative antioxidant efficiency values were calculated according to the method of Wang, et al. (1996). Values are expressed as micromoles of Trolox equivalents (TE) per gram of fresh weight.

\section{Extraction and Determination of Flavonoids}

Powdered oven-dried date fruits $(1 \mathrm{~g})$ were extracted in a Soxhlet extractor with ethanol. To the extract, $0.3 \mathrm{ml}$ of $\mathrm{NaNO}_{2}(1: 20)$ were added followed by $0.3 \mathrm{ml}$ of $\mathrm{AlCl}_{3}(1: 10)$. After $6 \mathrm{~min}, 2 \mathrm{ml} 1 \mathrm{~mol}$ litre $\mathrm{NaOH}$ were added. The absorbance was measured against a blank at $510 \mathrm{~nm}$ with a M8500 UV-Visible spectrophotometer (Taizhou Radio Factory) (Zhuang, et al., 1992).

\section{Measurement of Total Carotenoids}

Total carotenoids were extracted according to the method of Talcott and Howard (1999). The sample was extracted using $25 \mathrm{~mL}$ acetone/ ethanol $(1: 1 \mathrm{v} / \mathrm{v})$ with $200 \mathrm{mg} / \mathrm{L}$ butyl hydroxyl toluene (BHT). Samples were centrifuged at $1500 \mathrm{~g}$ for $15 \mathrm{~min}$. The supernatant was brought to 100 $\mathrm{mL}$ with the extraction solvent, and absorbance at $470 \mathrm{~nm}$ was measured using a UV-1601 Shimadzu spectrophotometer. Total carotenoids were calculated according to the method of Gross (1991).

\section{DNA Extraction}

Genomic DNA of five cultivars (Red Sukkary, Yellow Sukkary, and Naptet Sukkary) was extracted from $0.5 \mathrm{gm}$ leaflets. The leaves were first ground into fine powder with liquid nitrogen. DNA was extracted in $15 \mathrm{ml}$ of extraction buffer ( $350 \mathrm{mM}$ sorbitol, $5 \mathrm{mM}$ EDTA, $100 \mathrm{mM}$ Tris pH8, $0.5 \%$ sodium bisulphate), and the solution was filtered through a muslin cloth. The extract was centrifuged at $3000 \mathrm{~g}$ for 20 minutes, and the supernatant discarded. The precipitate was incubated in $30 \mathrm{ml}$ of lysis buffer (1.5 M NaCl, 100mM Tris-HCl pH 8, 20 mM EDTA, 4\% CTAB) for $4 \mathrm{~h}$ at $65^{\circ} \mathrm{C}$ with occasional mixing. Following incubation, $5 \mathrm{ml}$ of chloroform/isoamyl alcohol (24:1) was added to the tubes, mixed, and centrifuged at $2600 \mathrm{~g}$ for $10 \mathrm{~min}$. The aqueous phase was removed to a fresh tube and an equal volume of ice-cold isopropanol was added followed by centrifugation as above to precipitate the DNA. The pellet was 
washed in $70 \%$ ethanol and dissolved in TE buffer $(10 \mathrm{mM}$ Tris- $\mathrm{HCl}$, $\mathrm{pH} 8.0,0.1 \mathrm{mM}$ EDTA).

\section{RAPD-PCR Amplification}

Forty random primers were obtained from Pharmaicia Biotech (Amersham Pharmacia Biotech UK Limited, England HP7-9NA). RAPD analysis was conducted in a thermal cycler (Thermolyne Amplitron). The reaction mixture $(25 \mu \mathrm{L})$ contained 1x PCR buffer with $\mathrm{Mg} \mathrm{Cl}_{2}(50 \mathrm{mM}$ $\mathrm{K} \mathrm{Cl}, 10 \mathrm{mM}$ Tris- $\mathrm{HCl}$ (pH 9.0), $2 \mathrm{mM} \mathrm{Mg} \mathrm{Cl}_{2}$ and Triton X-100), 200 $\mu \mathrm{M}$ each of dATP, dCTP, dGTP, and dTTP, $30 \mathrm{ng}$ template DNA, $50 \mathrm{pM}$ of oligonucleotide primer and 1.5 unit of Taq polymerase. The mixtures were subjected to the following conditions: hold at $94^{\circ} \mathrm{C}$ for $2 \mathrm{~min}$ for starting, followed by 40 cycler of $94^{\circ} \mathrm{C}$ for $1 \mathrm{~min}, 36^{\circ} \mathrm{C}$ for $1 \mathrm{~min}$ and $72^{\circ} \mathrm{C}$ for $2 \mathrm{~min}$, and a final hold at $72^{\circ} \mathrm{C}$ for $5 \mathrm{~min}$. PCR products were visualized along with a DNA marker on $2 \%$ agarose gel with $1 \mathrm{X}$ TAE buffer and detected by staining with an ethidium bromide. Gels were photographed on Polaroid films under UV light.

\section{Data Handling and Cluster Analysis}

Data were scored for computer analysis on the basis of the presence or absence of the amplified products for each random primer. If a product was present in a genotype, it was designated "1", if absent it was designated " 0 " after excluding irreproducible bands. Pair-wise comparisons of genotypes, based on the presence or absence of unique and shared polymorphic products, were used to generate similarity coefficients based on simple matching. The similarity coefficients were then used to construct a dendrogram by UPGMA (unweighted pair-group method with arithmetical averages) using NTSYS-PC (Rohlf, 2001).

\section{Statistical Analysis}

Data were analyzed using a complete randomized design with three replicates per treatment, using the Student-Newman-Keul's Test. The least significant differences were used to compare means at $\mathrm{P} \leq 0.05$ according to the procedure outlined by Snedecor and Cochran (1980). The experiment was carried out for two successive seasons. 


\section{Results and Discussion}

\section{Antioxidant Activity (ORAC FL)}

Data in Table 1 compare the antioxidant activity of the three date fruit cultivars investigated using four different solvents of extraction. Data clearly show significant $(\mathrm{p} \leq 0.05)$ differences existing among the different cultivars investigated. Although extraction with ethanol: water (1:1) solvent gave the highest antioxidant activity for all the cultivars investigated, antioxidants extracted from "Naptet Sukkary" $c v$. showed significantly higher activity over the other two cvs., followed by "Yellow Sukkary", whereas "Red Sukkary" $c v$. afforded significantly lower antioxidant activity than all other investigated cultivars.

Table 1. Antioxidant activity a(ORAC FL) ( $\mu$ mol of ascorbic acid / g FW) of "Yellow Sukkary", "Red Sukkary", and "Naptet Sukkary" date cultivars, as affected by different extraction solvents ${ }^{\mathrm{b}}$.

\begin{tabular}{|l|c|c|c|c|}
\hline \multirow{2}{*}{ Date cultivars } & \multicolumn{4}{|c|}{ Extract solvents } \\
\cline { 2 - 5 } & Water & Phosphate buffer & $\begin{array}{c}\text { Ethanol: Water } \\
(\mathbf{1 : 1 )}\end{array}$ & Ethanol \\
\hline Yellow Sukkary & $1384 \mathrm{a}$ & $1044 \mathrm{c}$ & $1425 \mathrm{~b}$ & $1196 \mathrm{~b}$ \\
\hline Red Sukkary & $1035 \mathrm{~b}$ & $878 \mathrm{c}$ & $1221 \mathrm{c}$ & $946 \mathrm{c}$ \\
\hline Naptet Sukkary & $1616 \mathrm{a}$ & $1318 \mathrm{a}$ & $1981 \mathrm{a}$ & $1740 \mathrm{a}$ \\
\hline
\end{tabular}

antioxidant activity expressed as $\mu \mathrm{mol}$ of ascorbic acid / g FW.

${ }^{b}$ Means followed by the same letter, within a row are not significantly different $(p \geq 0.05)$.

Each value in the table is the mean of three replicates, and three measurements were conducted for each replicate.

These results indicate that antioxidants extracted with ethanol/water (50: $50 \mathrm{v} / \mathrm{v}$ ) yielded the highest recovery. This could be due to the solubility differences of the different types of the antioxidants in dates in ethanol, water, or their mixture.

\section{Antioxidant Efficiency (A E)}

Significant differences $(\mathrm{p} \leq 0.05)$ existed among antioxidant efficiency values (AE) of the different date cultivars investigated within the same solvent (Table 2). Comparing the antioxidant efficiency values of the three date fruit cultivars using four different extraction solvents, data clearly showed that extraction with ethanol: water (1:1) solvent gave 
the highest antioxidant efficiency for all the cultivars investigated. Antioxidants extracted from "Naptet Sukkary" $c v$. showed significantly higher efficiency values over the other two cultivars, followed by "Yellow Sukkary", whereas "Red Sukkary" cv. afforded significantly lower antioxidant efficiency than all other investigated cultivars. These results indicate that antioxidants contents of the tested cultivars are different from each other regarding both activity and efficiency values, which could indicate that the chemical composition of these three cultivars is not identical. This could be due to genetic variations between these cultivars. The chemical analysis of the date cultivars investigated support the data in Fig. 2 which clearly shows the genetic differences among these cultivars.

Table 2. Antioxidant efficiency "(A E) (DPPH Assay) of "Yellow Sukkary", "Red Sukkary", and "Naptet Sukkary" date cultivars, as affected by different extraction solvents". Values are expressed as micromoles of Trolox equivalents (TE) per gram of fresh weight.

\begin{tabular}{|l|c|c|c|c|}
\hline \multirow{2}{*}{ Date cultivars } & \multicolumn{4}{|c|}{ Extract solvents } \\
\cline { 2 - 5 } & Water & Phosphate buffer & $\begin{array}{c}\text { Ethanol: Water } \\
(\mathbf{1 : 1})\end{array}$ & Ethanol \\
\hline Yellow Sukkary & $61.0 \mathrm{~b}$ & $46.0 \mathrm{~b}$ & $62.8 \mathrm{a}$ & $52.7 \mathrm{~b}$ \\
\hline Red Sukkary & $45.6 \mathrm{c}$ & $38.7 \mathrm{c}$ & $53.8 \mathrm{c}$ & $41.7 \mathrm{c}$ \\
\hline Naptet Sukkary & $71.2 \mathrm{a}$ & $58.1 \mathrm{a}$ & $87.3 \mathrm{a}$ & $75.1 \mathrm{a}$ \\
\hline
\end{tabular}

${ }^{a}$ Means followed by the same letter, within a row are not significantly different $(p \geq 0.05)$.

${ }^{b}$ Values are expressed as micromoles of Trolox equivalents (TE) per gram of fresh weight.

Each value in the table is the mean of three replicates, and three measurements were conducted for each replicate.

\section{Phenolic Acids Contents}

\section{Bound Phenolics}

Significant differences $(\mathrm{p} \leq 0.05)$ were observed among bound phenolic fractions values of the different date cultivars under investigation (Table 3). "Red Sukkary" cultivar showed significantly higher values of bound protocatechuic, syringic, caffeic, coumaric, ferulic, hydroxy benzoic, and hydroxy cinnamic acids. However, no significant differences were observed between "Naptet Sukkary" and "Red Sukkary" cultivar as regarding their contents of bound syringic, caffeic, coumaric, ferulic, hydroxy benzoic, and hydroxy cinnamic acids. 
Yellow Sukkary cultivar did not show any significant superiority over the others except for bound protocatechuic and syringic compounds. These results indicate wide range of variations in bound phenolic fractions values of some of the date cultivars under investigation. On the other hand, there is a certain similarity in some other bound phenolic fractions values of some of the date cultivars under investigation, which could indicate a relationship between the genetic composition of these cultivars, but they are still different cultivars although the very close morphological characters of these cultivars.

Table 3. Bound phenolic acids contents (mg $\left.100 \mathrm{~g}^{-1} \mathrm{DW}\right)$ in "Yellow Sukkary", "Red Sukkary", and " Naptet Sukkary" date cultivars determined as a summation of both acid and alkaline hydrolysis measures*.

\begin{tabular}{|c|c|c|c|c|c|c|c|c|}
\hline \multirow[b]{2}{*}{ Cultivars } & \multicolumn{8}{|c|}{ Bound phenolic acids (mg $\left.100 \mathrm{~g}^{-1} \mathrm{DW}\right)$} \\
\hline & 童 & 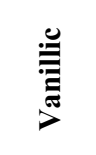 & 寜 & & نُ & & 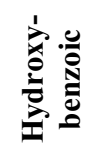 & 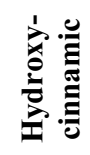 \\
\hline $\begin{array}{l}\text { Yellow } \\
\text { Sukkary }\end{array}$ & $0.83 \mathrm{a}$ & $0.29 \mathrm{c}$ & $0.25 \mathrm{a}$ & $0.49 \mathrm{c}$ & $0.35 \mathrm{~b}$ & $0.31 \mathrm{~b}$ & $4.53 \mathrm{~b}$ & $1.15 \mathrm{~b}$ \\
\hline $\begin{array}{l}\text { Red } \\
\text { Sukkary }\end{array}$ & $0.87 \mathrm{a}$ & $0.46 \mathrm{~b}$ & $0.22 \mathrm{a}$ & $0.93 \mathrm{a}$ & $0.54 \mathrm{a}$ & $0.88 \mathrm{a}$ & $5.46 \mathrm{a}$ & $2.35 \mathrm{a}$ \\
\hline $\begin{array}{l}\text { Naptet } \\
\text { Sukkary }\end{array}$ & $0.63 \mathrm{~b}$ & $0.67 \mathrm{a}$ & $0.2 \mathrm{a}$ & $0.80 \mathrm{~b}$ & $0.6 \mathrm{a}$ & $0.32 \mathrm{~b}$ & $5.62 \mathrm{a}$ & $2.12 \mathrm{a}$ \\
\hline
\end{tabular}

*Means followed by the same letter, within a column are not significantly different $(p \geq 0.05)$.

Each value in the table is the mean of three replicates, and three measurements were conducted for each replicate.

\section{Free Phenolics}

As regarding free phenolic fractions values of the different date cultivars under investigation, data in Table 4 clearly show that "Yellow Sukkary" cultivar contained significantly higher values of free protocatechuic, vanillic, syringic, and hydroxy benzoic acids compared with all other cultivars. However, no significant differences were observed between "Yellow Sukkary" and "Red Sukkary" cultivars as regarding their contents of free syringic acid. "Naptet Sukkary" cultivar showed significantly lower values for all measured free phenolic compounds compared to other two cultivars. No free vanillic acid was 
detected in "Red Sukkary", whereas no free protocatechuic acid was detected in "Naptet Sukkary" cultivar. These results indicate a wide range of variations in free phenolic fractions values of some of the date cultivars under investigation. On the other hand, there is a certain similarity in some other free phenolic fractions values of some of the date cultivars under investigation, which could indicate a genetic relationship between these cultivars, but they are still different cultivars although the very close morphological characters of these cultivars.

Table 4. Free phenolic acids contents (mg $\left.100 \mathrm{~g}^{-1} \mathrm{DW}\right)$ in "Yellow Sukkary", " Red Sukkary", and " Naptet Sukkary" date cultivars*.

\begin{tabular}{|l|c|c|c|c|}
\hline \multirow{2}{*}{ Cultivars } & \multicolumn{4}{|c|}{ Free phenolic acids $\left(\mathbf{m g ~} \mathbf{1 0 0} \mathbf{g}^{-\mathbf{1}} \mathbf{D W}\right)$} \\
\cline { 2 - 5 } & Protocatechuic & Vanillic & Syringic & $\begin{array}{c}\text { Hydroxy } \\
\text { benzoic }\end{array}$ \\
\hline $\begin{array}{l}\text { Yellow } \\
\text { Sukkary }\end{array}$ & $3.27 \mathrm{a}$ & $0.35 \mathrm{a}$ & $1.45 \mathrm{a}$ & $6.22 \mathrm{a}$ \\
\hline $\begin{array}{l}\text { Red } \\
\text { Sukkary }\end{array}$ & $1.73 \mathrm{~b}$ & nd c & $1.50 \mathrm{a}$ & $3.49 \mathrm{~b}$ \\
\hline $\begin{array}{l}\text { Naptet } \\
\text { Sukkary }\end{array}$ & nd c & $0.12 \mathrm{~b}$ & $0.64 \mathrm{~b}$ & $1.25 \mathrm{c}$ \\
\hline
\end{tabular}

* Means followed by the same letter, within a column are not significantly different $(p \geq 0.05)$.

Each value in the table is the mean of three replicates, and three measurements were conducted for each replicate.

\section{Flavonoids and Carotenoids Contents}

Flavonoids showed significant differences $(p \geq 0.05)$ among the varieties examined (Fig. 1). The highest content of flavonoids was presented in "Red Sukkary" (4.47 mg/100g fresh weight), followed by "Naptet Sukkary" (2.26 mg/100g fresh weight) and "Yellow Sukkary" $(2.13 \mathrm{mg} / 100 \mathrm{~g}$ fresh weight). These differences are related to the color of these cultivars ("Red Sukkary" is red color at full mature stage and the red color decreases as the fruits proceed towards ripening stage while "Naptet Sukkary" is dark yellow with dark brown color and "Yellow Sukkary" is yellow with slight dark brown color less than "Naptet Sukkary"). The highest total content of flavonoids in "Red Sukkary" was expected due to its red color, whereas the other two cultivars are yellow.

Total carotenoids content in fresh date fruits of both "Red Sukkary" and "Naptet Sukkary" cultivars were significantly higher than those of "Yellow Sukkary" (Fig. 1). No significant differences were observed 
between both "Red Sukkary" and "Naptet Sukkary" cultivars. Similar to flavonoids, carotenoids show another chemical composition differences between the three date cultivars studied which could give good reason for using the fingerprint technique to distinguish between the offshoots of these cultivars before planting as the morphological differences among their offshoots are very minor.

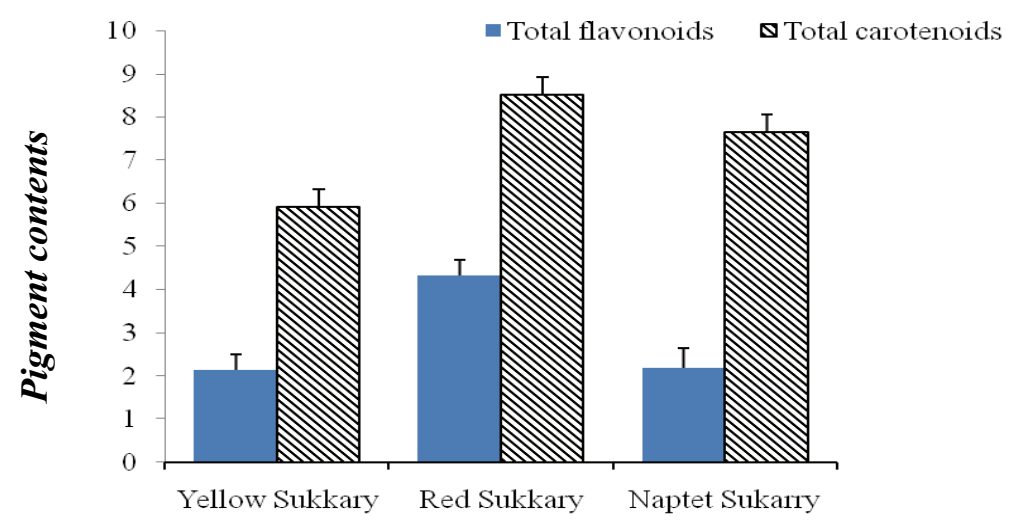

Cultivars

Fig. 1. Total flavonoids and carotenoids content $(\mathrm{mg} / 100 \mathrm{~g}$ fresh weight) of "Yellow Sukkary", "Red Sukkary", and "Naptet Sukkary" date cultivars at Tamr stage of development. Vertical bars show standard errors of three replicates. Each value in the figure is the mean of three replicates. Three measurements were conducted for each replicate.

\section{Screening for a Polymorphic Primers}

Forty primers of arbitrary nucleotide sequence were used to amplify DNA segments from three date palm cultivars (Red Sukkary, Yellow Sukkary, and Naptet Sukkary) from Saudi well known dates. The number of amplification bands per primer varied between 0 and 11 . Of the 40 primers tested, 16 were selected for further analysis based on the intensity, size and number of amplified products (Table 5). Analysis of the 16 selected primers among the three cultivars included in this study generated 115 bands, 27 of which were polymorphic. There were 1.7 polymorphic bands per primers in average. Examples of polymorphism are shown in Fig. 2. All three date palm cultivars were distinguishable by their band patterns. 
Table 5. Selected primers with the numbers of amplified products and polymorphic fragments.

\begin{tabular}{|c|c|c|}
\hline Primer & No. of amplification products & No. of polymorphic products \\
\hline OP-A01 & 9 & 2 \\
OP-A02 & 7 & 0 \\
OP-A03 & 6 & 0 \\
OP-A04 & 9 & 2 \\
OP-A08 & 6 & 1 \\
OP-A13 & 7 & 1 \\
OP-A16 & 8 & 3 \\
OP-A18 & 10 & 3 \\
OP-A20 & 7 & 1 \\
OP-F04 & 7 & 2 \\
OP-F05 & 8 & 2 \\
OP-F07 & 11 & 3 \\
OP-F08 & 7 & 3 \\
OP-F09 & 6 & 2 \\
OP-F11 & 5 & 1 \\
OP-F12 & 7 & 1 \\
\hline
\end{tabular}

\section{DS DSR DSY DS DSR DSY DS DSR DSY DS DSR DSY}

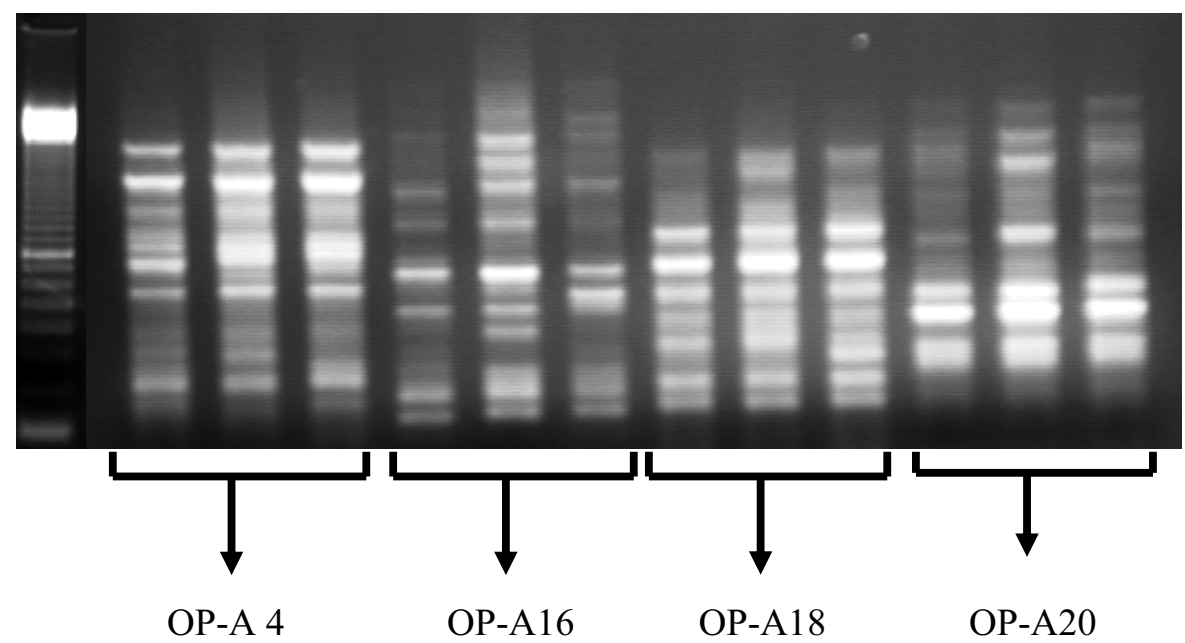

Fig. 2. Polymorphism revealed using RAPD primers (OPA-04, OPA-16, OPA-18, and OPA20) to amplify genomic DNA purified from cultivars of date palm (left to right) Naptet Sukkary (DS), Red Sukkary (DSR), and Yellow Sukkary (DSY). M lane is 1 kbp ladder DNA marker. 
Polymorphism between cultivars can arise through: nucleotide changes that prevent amplification by introducing a mismatch at one priming site; deletion of a priming site; insertions that render priming sites too distant to support amplification; and insertions or deletions that change the size of the amplified product (Williams, et al., 1990).

The overall exhibited polymorphism in this study is rather high in comparison with results reported by Sedra, et al. (1998) and Ben Abdallah, et al. (2000). The last study indicated that 11 of the 122 primers tested were selected as reproducible among four cultivars of date palm.

\section{Cluster Analysis}

The RAPD markers produced by 16 primers were tested to construct a similarity matrix (Table 6). The genetic similarity among all date palm cultivars ranged from 0.81 to 0.87 . Red Sukkary cultivar was the closest relative $(0.84)$ to Yellow Sukkary cultivar. Moreover, Naptet Sukkary cultivar was quite distant from other cultivars.

Table 6. Simple matching coefficients of similarity determined from analysis using $\mathbf{1 1 5}$ RAPD loci.

\begin{tabular}{|l|c|c|c|}
\hline \multicolumn{1}{|c|}{ Cultivars } & DS & DSR & DSY \\
\hline Naptet Sukkary (DS) & 1.00 & & \\
\hline Red Sukkary (DSR) & 0.81 & 1.00 & \\
\hline Yellow Sukkary (DSY) & 0.83 & 0.87 & 1.00 \\
\hline
\end{tabular}

Cluster analysis was conducted to generate dendrogram including relationship between date palm cultivars. The dendrogram constructed from simple matching with UPGMA analysis revealed two main clusters (Fig. 3). Cluster I contained Red Sukkary and Yellow Sukkary cultivars. Cluster II contained Sukkary cultivar. The fact that Red Sukkary cultivar did not markedly diverge from Yellow Sukkary cultivar suggests a narrow genetic diversity of populations from which these cultivars have been derived. On the other hand, Sukkary cultivar was less similar to Red Sukkary and Yellow Sukkary cultivars. This result may be due to the hypothesis which suggest that Red Sukkary is a mutant offshoot from Yellow Sukkary, while Naptet Sukkary is a seedling from Yellow 
Sukkary, this hypothesis could lead to the fact that the genetic composition of Red Sukkary is closer to Yellow Sukkary than Naptet Sukkary. RAPD- markers should therefore be of high value for date palm germplasm characterization and genetic maintenance (Sedra, et al., 1998 and Al-Moshileh, et al., 2004). In either case, a prediction of genetic similarity based on genetic markers provides more information than can gained from pedigree information alone (Tinker, et al., 1993). Moreover, Ben-Abdallah, et al., (2000) suggested that RAPD markers can be used for varital identification, evaluation of date palm and for studying the genetic diversity of cultivars.

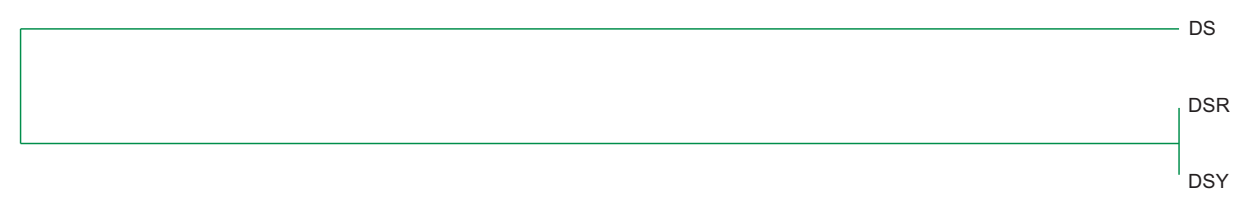

\begin{tabular}{cccc}
\hline 0.82 & 0.84 & 0.86 & 0.87 \\
& Coefficient & &
\end{tabular}

Fig. 3. Dendrogram constructed from similarity coefficients and showing the clustering of date palm cultivars.

\section{References}

Al-Farsi, M., Alasalvar, C., Morris, A., Baron, M. and Shahidi, F. (2005) Comparison of antioxidant activity, anthocyanins, carotenoids, and phenolics of three native fresh and sundried date (Phoenix dactylifera L.) varieties grown in Oman, J. Agric. Food Chem., 53: $7592-7599$.

Al-Moshileh, A., Motawei, M.I., Al-Wasel, A. and Abdel-Latif, T. (2004) Identification of some date palm (Phoenix dactylifera L.) cultivars in Saudi Arabia using RAPD fingerprints, Journal of Science Research, 9(2): 1-3

Amiot, M.J., Tacchini, M., Aubert, S. and Nicholas, J. (1992) Phenolic composition and browning susceptibility of various apple cultivars at maturity, J. Food Sci., 57: 958-962.

Ben-Abdalla, A., Stiti, K., Lepoivre, P. and Jardin, P. (2000) Date palm (Phoenix dactylifera L.) cultivar identification using random amplified polymorphic DNA (RAPD), Cahiers Agricultures, 9: 103-107.

Bushway, A.A., Hu, W. and Shupp, J.M. (2002) Quality characteristics of five disease resistant apple cultivars, J. Amer. Pom. Soc., 56(2): 94-105.

Eberhardt, M.V., Lee, C.Y. and Liu, R.H. (2000) Antioxidant activity of fresh apples, Nature, 405: 903-904. 
FAO (1984) FAO Production Year Book, Food and Agriculture Organization of the United Nations, Rome, Italy.

Feucht, W., Treutter, E. and Christ, E. (1992) The precise localization of catechins and proanthocyanidins in protective layers around fungal infections, J. Plant Diseases and ProtectionI, 99 (4): 404-413.

Frankel, E. (1995) Nutritional benefits of flavonoids, International Conference on Food Factors: Chemistry and Cancer Prevention, Hamamatsu, Japan, Abstracts, C6-2.

Goupy, P., Amiot, M.J., Richard-Forget, F., Duprat, F., Aubert, S. and Nicholas, J. (1995) Enzymatic browning of model solutions and apple phenolic extracts by apple polyphenoloxidase, J. Food Sci., 60: 497-501.

Gross, J. (1991) Pigments in Vegetables, Chlorophylls and Carotenoids, Van Nostrand Reinhold: New York.

Huang, D., Ou, B., Hampsch-Woodill, M., Flanagan, J.A. and Deemer, E.K. (2002) Development and validation of oxygen radical absorbance capacity assay for lipophilic antioxidants using randomly methylated B-cyclodextrin as the solubility enhancer, J. Agric. Food Chem., 50: 1815-1821.

Kalt, W., Ryan, D.A.J., Duy, J.C., Prior, R.L., Ehlenfeldt, M.K. and Vander, S.P.K. (2001) Interspecific variation in anthocyanins, phenolics, and antioxidant capacity among genotypes of highbush and lowbush blueberries (Vaccinium cyanococcus spp.), J. Agric. Food Chem., 49: 4761- 4767.

Larson, R.A. (1988) The antioxidants of higher plants, Phytochemistry, 27: 969-978.

Mayr, U., Treutter, D., Santo-Buelga, C., Bauer, H. and Feucht, W. (1996) Developmental changes in the phenol concentrations of Golden Delicious apple fruits and leaves, Phytochem., 38 (5): 1151-1155.

Ou, B., Hampsch-Woodill M. and Prior, R.L. (2001) Development and validation of an Improved oxygen radical absorbance capacity assay using fluorescein as the fluorescent probe, J. Agric. Food Chem., 49: 4619-4626.

Robards, K., Prenzler, P., Tucker, P., Swatsitang, G. and Glover, W. (1999) Phenolic compounds and their roles in oxidation process in fruits, Food Chem., 66: 401-436.

Rohlf, F. J. (2001) NTSYS-PC Numerical Taxonomy and Multivariate System, version 2.1. Applied Biostatistics Inc., New York.

Shahidi, F. and Naczk, M. (2004) Phenolics in Food Nutraceuticals, CRC Press: Boca Raton, FL.

Sedra, H., Lashermes, P., Trouslot, P., Combes, C. and Hamon, S. (1998) Identification and genetic analysis of date palm (Phoenix dactylifera L.) varieties from Morocco using RAPD markers, EphyticaI, 103: 75-82.

Snedecor, G.W. and Cochran, W.G. (1980) Statistical Methods, $7^{\text {th }}$ Ed., Iowa State Univ. Press, Ames, Iowa, USA.

Talcott, S.T. and Howard, L.R. (1999) Phenolic autoxidation is responsible for color degradation in processed carrot puree, J. Agric. Food Chem., 47: 2109-2115.

Tinker, N.A., Fortin, M.G. and Mather, D.E. (1993) Random amplified polymorphic DNA and pedgree relationships in spring barley, Theor Appl Genet., 79: 976-984.

Van der Sluis, A.A., Dekker, M., Skrede, G. and Jongen, W.M.F. (2002) Activity and concentration of polyphenolic antioxidants in apple juice, 1. Effect of existing production methods, J. Agric. Food Chem., 50: 7211-7219.

Velioglu, Y.S., Cazza, G., Gao, L. and Oomah, B.D. (1998) Antioxidant activity and total phenolics in selected fruits, vegetables, and grain products, J. Agric. Food Chem., 46: 41134117.

Vinson, J.A., Su, X., Zubik, L. and Bose, P. (2001) Phenol antioxidant quantity and quality in foods and fruits, J. Agric. Food Chem., 49: 5315-5321. 
Wang, H., Cao, G. and Prior, R.L. (1996) Total antioxidant capacity of fruits, J. Agric. Food Chem., 44: 701-705.

Wang, S.Y., CAas, J.L., Payne, J.A. and Galleta, G. (1994) Ellagic acid in small fruits, cashews, and other plants, J. Small Fruit Viticulture, 2(4): 39-49.

Williams, G.K., Kubelik, A.R., Livak, K.L., Rafalski, J.A. and Tingey, S.V. (1990) DNA polymorphism amplified by arbitrary primers are useful as genetic markers, Nucleic Acids Research, 18: 6531-6535.

Zhuang, X.P., Lu, Y.Y. and Yang, G.S. (1992) Extraction and determination of flavonoid in ginkgo, Chinese Herbal Medicine, 23: 122-124. 


\section{استخدام البصمة الور اثية بطريقة RAPD و التركيب الكيميائي للثمار للتعرف على بعض أصناف نخيل التمر}

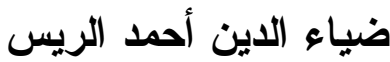

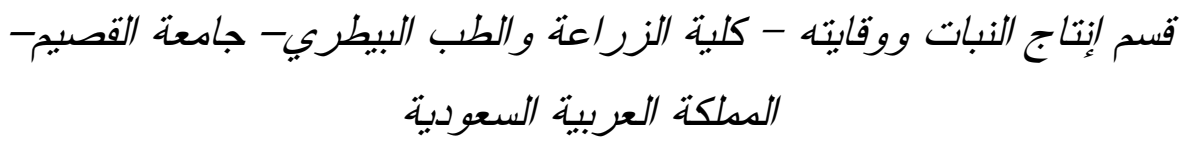

الستخلص. تم استخدام طريقة RAPD (التكبير العشوائي لقطع الحامض النووي"DNA") وبعض المكونات الكيميائية (نشاط وكفاءة

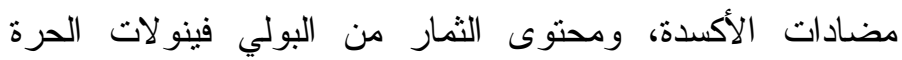
و المرتبطة ، و الفلافونويد والكاروتينويد) لتمييز الثباينات الور اثية

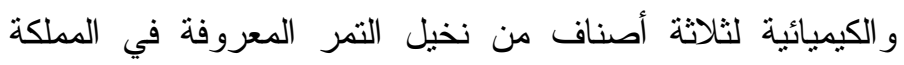

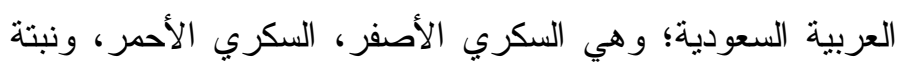

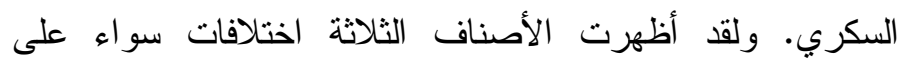
مستوى الحامض النووي أو على مستوى التزكيب الكيميائي للثمار .

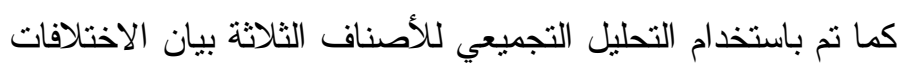

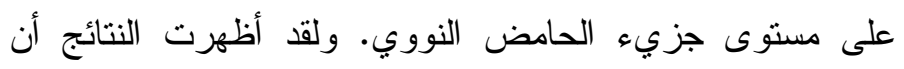

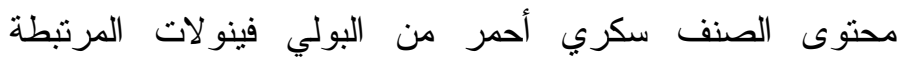

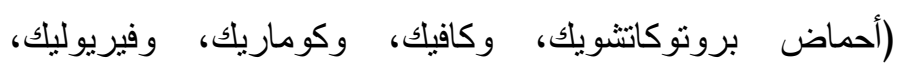

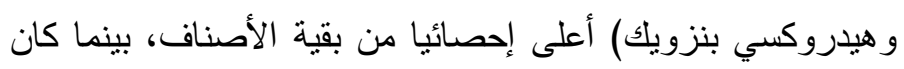

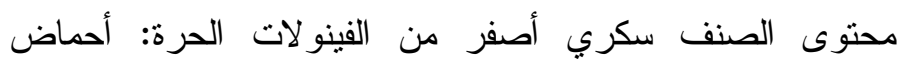

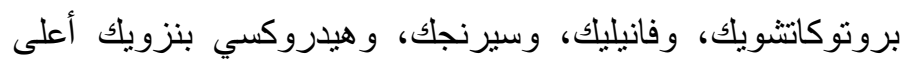

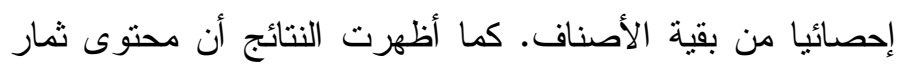

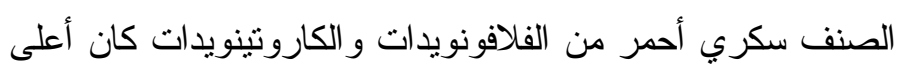
إحصائيا من بقية الأصناف. تم اختبار مدى ملائمة طريقة التكبير 
العشوائي لقطع الحامض النووي الديوكسي رييوز RAPD كأدلة

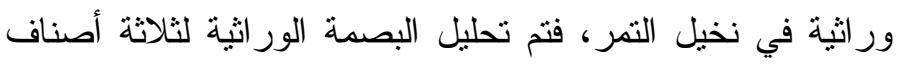
من نخيل التمر وهي نبتة سكري و السكري الأصفر و السكري

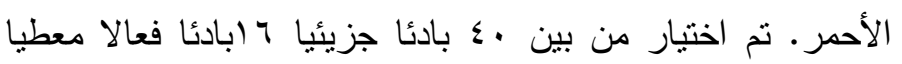

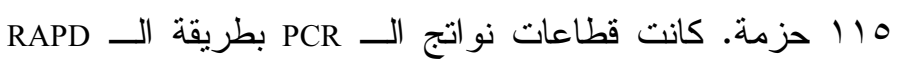

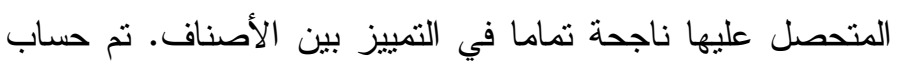

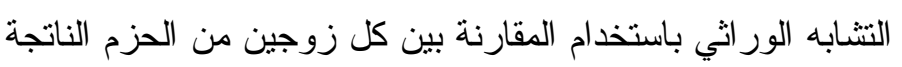

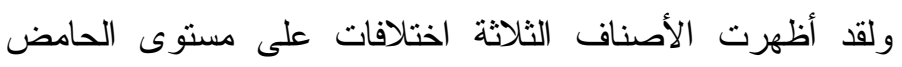
النووي. كما تم باستخدام التحليل التجميعي للأصناف الثلاثة بيان

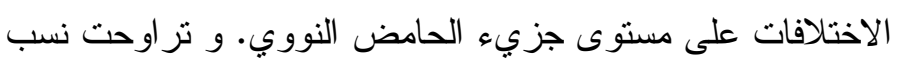

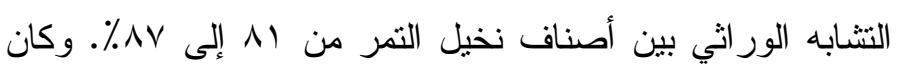

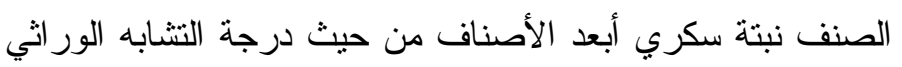

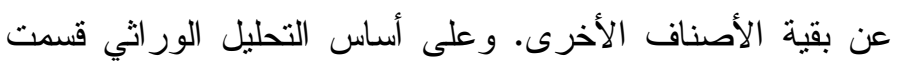
الأصناف إلي مجموعتين: المجموعة الأولي تشتمل على صنى صنفي الاصني

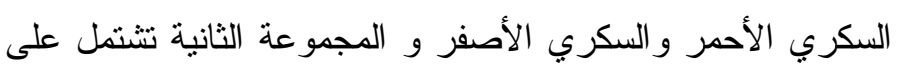

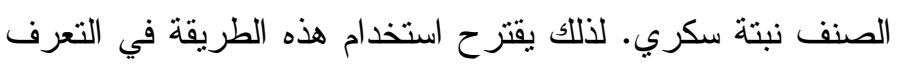
على أصناف النخيل المختلفة، وكذلك في دراسة التباعد الوراثي لئي بين الأصناف. 